\title{
License Agreement in The Patent Commercialization in Correlation to The Regulation About Patent
}

\author{
Syahrul Mahmud ${ }^{1}$, Imas Rosidawati $W^{2}$, Happy Yulia $A^{3}$ \\ \{syahrulm.uninus@gmail.com ${ }^{1}$, imasrosidawati@uninus.ac.id ${ }^{2}$, \\ happy.anggraeni@uninus.ac.id ${ }^{3}$ \} \\ 1,2,3 Master of Law Studies Program Post-Graduate School, Nusantara Islamic University, Bandung, \\ Indonesia
}

\begin{abstract}
Technology improvement of the country proves civilization development as the access by this improvement is beneficial for people easiness, comfort, and welfare. And also science and technology are created for people quality of life improvement. University is one of the non-financial institutions whose function is not only for education and creation of educated people but also as an asset for society such as technological works for patent product and can be applied in the industrial activity. The approach method used in this study uses a normative juridical approach. Normative juridical is research that discusses doctrines or principles in law. The protection of patent commercialization for the inventors is to be empowered and to be beneficial for the society through the license agreement with the inventor's partners. The license agreement for the Inventors fulfills the economy equality right.
\end{abstract}

Keywords: patent, patent commercialization, license agreement, economy equality right

\section{INTRODUCTION}

Technology improvement is one of the indicators of civilization development as access to technology is beneficial for humankind in easiness, comfort, and welfare. Science and technology benefit is also to improve people quality of life. The technology improvement can be seen on the facts of computer development (microelectronics), material science, biotechnology, and information technology.

The country of Indonesia have ratified the Agreement on Trade-Related Aspect of Intellectual Property Rights/TRIPs) within the Agreement Establishing the World Trade Organization). Intellectual property right is one of critical components on the global trade [1]. In consequence, the globalization principles on the world trade regulations must be followed [2] An impact of this convention involvement is to expand the national Intellectual Property Right scope, to improve commitment for implementation [3].

Intellectual property right is gained by the intellectual works from the individual or group efforts[4]. Then it is called as Intellectual Property. It can be the works on technology, science, art or literature. The experts define Intellectual Property in three aspects of exclusive right given by the law; in correlation with people efforts based on intellectual ability; and it has economical 
value. The patent right is an exclusive right given by the country to the inventor due to his invention on technology within the period of time. The patent right is given in the 20 year period and can not be extended. It is expected that the inventor develops more inventions. The society also have access the patent benefits and when the patent duration is achieved, the patent product belongs to the public then it is called public domain.

According to the law of Undang-Undang No. 13 of 2016 about Patent, that is called as Patent Law, the exclusive right is granted by the country to the inventor due to his invention on technology within the period of time to let himself or to authorize other people to use it. Individual intention to design and to develop his creativity and innovation on intellectual property is to gain an exclusive right within the Economic Right, besides Moral Right on the Intellectual Right and it is acknowledged on the international Intellectual Property convention. The exclusive right has commercial value by implementing intellectual property right. But not all of the intellectual property owners use their right, sometimes they authorize it to someone else. The practice is accommodated in the intellectual property law through the license authorization and has a financial impact that is called as royalty.

The license authorization, according to the intellectual property principles, is the economic right transfer and still must require acknowledgment of the inventor as respect and economic equal right for him. The license holder can be authorized for the partial property right, not the whole system. The inventor also can not authorize the property right out of his invention scope. An idea, innovation, and other creativity expressions as personal rights are protected by intellectual property law. The problem raised in this research is how to protect the patent commercialization in order to be useful and beneficial for the society and how can the license agreement on patent right fulfill the economic equality right for the inventor?

\section{METHOD}

The approach method used in this study uses a normative juridical approach. Normative juridical is research that discusses doctrines or principles in law.[5] The normative juridical approach is used to analyze various laws and regulations and matters related to patent protection. The juridical aspect is the Patent Law which is supported by a licensing agreement between the licensee and the inventor.

This research carried out through a normative juridical approach intends to see the development of legal solutions to problems related to patent protection resulting from the commercialization of a tertiary institution with the equality of inventor's economic rights based on the license agreement between the two parties.

The data for this research comes from secondary data supported by primary data. Definition of secondary data is data obtained from library materials, while primary data is data obtained directly from the first source. Secondary data includes primary legal material and secondary legal material [6]. Secondary data in this study are in the form of legal materials as follows: 1) Primary Law Materials, including a) Civil Code b) Law Number 13 of 2016 concerning Patents c) License agreement between higher education institutions and inventors; 2) Secondary Legal Materials are the opinions of legal experts that can be found in the literature in the form of legal books, internet media, and legal articles and can also be found in legal journals relating to patents.

\section{RESULT AND DISCUSSION}

\subsection{License Agreement}


The word of "license" simply means an authorization granted by the intellectual property owner (inventor) to the other people by the agreed terms and conditions for the determined goal, area and time period. According to Tim Lindsey [7], license is permit authorization granted by the license owner to the license recipient to use the property right of the owner based on conditions within the period of time with royalty in a return [8].

According to Ruslan Saleh, license is derived from the Latin language of "Licentia" [9]. License mechanism results authorization or permits to an individual or other people to use something that is not permitted to be utilized before. License is always linked as a privilege to do something by an individual or other people. In other words, the authorization of the inventor is transferred to other people by the license.

The license agreement, like other general agreement, is where two persons or more agree and establish a binding deal to do something in the welfare area [8]. An agreement in daily practice means a series of word contains promises and acceptances that are spelled and written. Both parties involved in the agreement are truly bonded each other and have law certainty. An agreement is formed in obligation: a) To give something b) To do something c) To not to do something [10].

Generally the agreement elements are as follow: (a) Essentalia is an absolute part of the agreement that it is not valid with the absence of this part. In a trade agreement, price and goods are the essentialia part and no trade happen when these elements not exist. (b) Naturalia is part of law as a regulatory means. For instance in a trade agreement, a naturalia is the obligation of the seller to guarantee no hidden defects on goods. (c) Accidentalia is an additional condition that is not covered in the common law. For example are AC and other accessories on a car trade agreement [10].

Business wise, license agreement can be a diversification effort and to increase profit. In addition, Nicolas S. Gikkas in the International Licenning of Intelectual Property: The Promise and The Peril, that was quoted by Wijaya, there are several considerations why the business owner take the license authorization option: a) License reach product market out of the existing one. b) License accelerate business development in the capital intensive industry by transferring several production processes through the technology license model. c) License enhance product market penetration and support market oriented business. d) License create profit on product image and good will from the license owner. e) The license authorization may have the license owner controlled their business without additional significant cost [10].

Drupsteen has different measurement to differ various license agreements [12]. The first measurement is economical goal of the license agreement. The second one is which law to be used to achieve the goal. License agreement terminology is frequently used in the trading world, where the one party needs something to be developed to increase the business profit that is the work or product created by others and he needs license agreement for this goal.

Patent license agreement is regulated on the article $76-107$ Law number 13 of 2016 as follow:

Article 76 consists of:

(1) The patent owner has the right to authorize license to other people based on license agreement which is exclusively or not exclusively to perform actions as mentioned in the article 19.

(2) License agreement on first point (1) covers whole or part of actions mentioned on article 19. 
(3) License agreement on first point (1) is valid within the period of time and in the region of Republik Indonesia.

License provision is the important role in the industry development when the invention ability is still on development. Article 80 of Patent Law mentions about other regulations of license agreement that is covered on the ministerial regulation..

Article 78 of Patent Law states: "License agreement is prohibited in containing provisions that harm Indonesian national interests or restrictions in inhibiting Indonesian people ability for technology transfer, mastery, and development.

The problem in license agreement is when the persons involved don't register it to the patent office due to the reason of contract freedom. According to article 79 of Patent Law, this condition has no law implication to the third party so that the agreement is not valid on the law or no further action from the Law General Directorate. Agreement cancellation is not government authority as the law correlation is private law, not public law.

Technology development is dedicated to technology mastery and utilization to support transformation towards competitive advantage based economy. In order to have sustainable support to the technology development, we need to strengthen national innovation system by public and private research board, natural resources utilization, human resources empowerment, information technology network, research culture, technology development and application on strategical fields in scientific publication, technology services, and even technology entrepreneurship. Technology is the main concerns in rich countries for development and economy growth measures. In those countries, economy and technology policy is integrated and in line for national competitiveness. The policy is dedicated for technology utilization in production sector for national economy development and domestic technology appreciation.

\subsection{Protection on Patent Commercialization}

License right of the patent means the right to utilize it commercially. The license holder must assure that it is applied and implemented as per its purposes for optimum results to all parties in the agreement. Economy matters can not be avoided on the intellectual property right. It is correlated to the commercialization. Regarding the patent, TRIPs regulate stronger about patentable subject matter that is the protection to all inventions in all fields of technology includes pharmaceutical patent and even bio technology. Patent is only given to the new inventions, have inventive step and industrially applicable.

The industrially applicable means it can't avoid the capital issues. No patent that can not be applied in the production process. It is clear that the property protection is not only on logical creativity, but also on industrial activity. The main goal of investor is not losing profit gained from capital investment on patent products.

License agreement is applied based on normal commitments unless there's another commitment for the period of time that not longer than the patent's protection time. The similar situation is applied to the limitation of patent utilization for technology transfer subject. The time period of this kind of patent can be limited on the agreement, as follow: a ) Limitation of patent utilization is only for technology transfer product. b) Region limitation of the patent that it's not utilized in whole region of Indonesia. c) Time limitation of the license that it is shorter than patent's protection time.

License authorization has advantage to the patent owner. A series of research, development and technology transfer can be performed by other party but the patent owner still deserve royalty. The royalty value may be smaller than real profit gained if the inventor produces patent 
goods on his own. However, it will need big investment so that license authorization model is still beneficial.

Basically license is held by the authorized party, however, the license agreement can accommodate the license transfer to the third party. If this commitment is not stated on the agreement, the license holder can not do this practice. Utilization of patent listed in Indonesia by the authorized party means brand usage by the patent owner.

License agreement is prohibited containing provisions that harm Indonesia economy directly or indirectly or containing restrictions on Indonesian people ability for technology development. Brand application as an intellectual property application is dedicated to support economy and technology development. The General Director must refuse license agreement proposal that contains the prohibitions through the written letter to the patent owner or the authorized party.

\section{CONCLUSIONS}

Commercialization protection on the intellectual property right in the patent system to be empowered and be beneficial for society through license agreement. The license agreement, where the patent product development is on operational stage, is actually initiated by a memorandum of understanding of both parties. License agreement on patent is dedicated to the economy equality right.

\section{ACKNOWLEDGMENTS}

Master of Law Studies Program Post-Graduate School of Islamic University of Nusantara, Bandung, Indonesia. This research is funded by DIPA Kopertis Region IV-West Java Banten, Ministry of Research, Technology, and Higher Education, in accordance with Letter of Agreement of Research of Decentralized Grant Research Fiscal Year 2018 Higher Education Research Program of Higher Education Number: 0030-B/LPPM-UIN/11/2018.

\section{REFERENCES}

[1] Undang-undang RI Nomor 7 tahun 1994 Tentang Pengesahan Agreement Establishing the World Trade Organization (Persetujuan Pembentukan Organisasi Perdagangan Dunia), disahkan dan diundangkan pada Tanggal 2 November 1994 dalam Lembaran Negara RI Tahun 1994 Nomor 57.

[2] I. R. Wiradirja. "Konsep Perlindungan Pengetahuan tradisional Berdasarkan Asas Keadilan Melalui Sui Generis Intellectual Property System”. Jurnal Hukum IUS QUIS IUSTUM (UII), Vol. 20 No. 02. pp. 2, 2013.

[3] I. R. Wiradirja and E. Santoso. "Prevention Of Trademark Infringement Through The Role Of Customs Control Related To Consumer Protection In Indonesia, International Journal of Business and Management Studies“. Central Connecticut State University Journal, Vol. 2, No. 2, pp. 151-161, 2013.

[4] Z. Ali. Metode Penelitian Hukum. Sinar Grafika: Jakarta. pp.24, 2010.

[5] S. Soekanto and S. Mamudji. Penelitian Hukum Normatif Suatu Tinjauan Singkat. Jakarta: Raja Grafindo Persada. pp.14, 2012.

[6] Surahno. Sejarah HKI di Indonesia., Jakarta: Universitas Terbuka. pp. 1.4, 2014.

[7] E. Hidayati. "Komersialisasi Hak Kekayaan Intelektual (HKI) Melalui Lisensi". Workshop Lisensi dan Komersialisasi HKI Bagi Dosen, Universitas Negeri Yogyakarta. p. 6, 1991.

[8] T. Lindsey et. al. (ed). "Hak Kekayaan Intelektual Suatu Pengantar". Bandung: Alumni, pp. 132, 2017. 
[9] E. Hidayati. "Komersialisasi Hak Kekayaan Intelektual (HKI) Melalui Lisensi“, Workshop Lisensi dan Komersialisasi HKI Bagi Dosen, Universitas Negeri Yogyakarta. pp. 6, 2014.

[10] A. Busro. Hukum Perikatan Berdasar Buku III KUH Perdata. Yogyakarta: Percetakan Pohon Cahaya. pp. 67, 2012.

[11] G. Supramono. Hak Cipta dan Aspek-Aspek Hukumnya. Jakarta: Rineka Cipta. pp.48, 2010.

[12] Th. Drupsteen. Lampiran pada Pengantar Hukum Perizinan, Terjemahan M. Soetopo, Kerjasama Hukum Indonesia-Belanda, dalam Dewi Astuty Mochtar : Perjanjian Lisensi Alih Teknologi dalam Pengembangan Teknologi Indonesia. Bandung: PT. Alumni, pp. 11, 2001. 